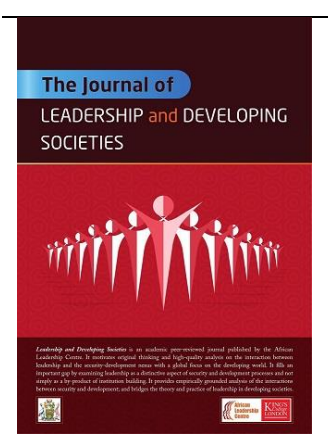

\title{
ARTICLE
}

\section{Revisiting Governance: Extended Statehood in Africa and Beyond*}

Olaf Bachmann'a and ‘Funmi Olonisakin ${ }^{\mathrm{b}}$

Available online 23 December 2020

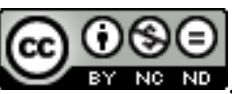

\begin{abstract}
This article sets the theme for this issue. Weberian understanding of statehood has been valid and dominant for 100 years. However, it no longer reflects the complex dynamics of the superstructure resting on the social contract. One must acknowledge the widening frame of social and political influence and take it into account to make true sense of decades of failure in attempted state-building. Africa provides the scene for this argument as original focus of an ALC research project on the State in, and of, the Global South. Resulting from empirical evidence and analysis, this article not only offers the post-Weberian model of Extended Statehood, but also suggests its applicability within the realities of multilevel governance. Formal political order, even if remaining essential, has become a codependent element subject to fluctuating spheres of power. This research makes such dynamics visible.
\end{abstract}

Keywords: multi-level governance; extended statehood; African state-building; Max Weber

\section{INTRODUCTION}

The central ideas about what constitutes a [successful] state have been challenged in tangible ways in recent years, especially in the context of globalisation. The foundational ideas of sovereignty - juridical and empirical - that have been held sacrosanct and to which newly created and/or persistently 'weak' states aspire, are being called into question. Interestingly, the need to re-evaluate the key ideas underpinning statehood is not driven purely by events or situations in Africa and the Global South, which now create only a momentary pause in acknowledgement of the 'typical basket-case'.

\footnotetext{
* A version of this paper has been previously published as Bachmann, Olaf, Funmi Olonisakin, and Fouad G. Marei (2020), 'Revisiting Governance: Extended Statehood in Africa and Beyond', in Was es (heute) heißt, Soldat zu sein, ed. by Gerhard Kümmel (Baden-Baden: Nomos), pp. 145-169.

a Visiting Senior Research Fellow at King's College London

b Professor of Security, Leadership and Development and Vice-Principal/Vice-President International at King's College London
}

Corresponding author: Olaf Bachmann, African Leadership Centre, King's College London Email: olaf.2.bachmann@kcl.ac.uk 
Rather, the need for stock-taking is compelled by the seemingly global nature of recent trends, which challenge some of the key ideas of statehood. Incidences of violent extremism, terrorism and other armed violence that have created insecurities in the US and a number of European countries in recent times drive home the realities of contemporary challenges to the state.

The territorial jurisdiction that underpins statehood and the need to maintain the integrity of a designated territory as a legal entity under international law is perhaps the first undisputed idea of statehood. This idea has come to stay since Westphalia. Most state actors often claim this de jure right and guard it zealously regardless of the state's capacity to maintain territorial integrity. Thus, what obtains in actuality becomes vitally important when investigating what constitutes a state. Max Weber's work stands out in this regard since his seminal inaugural lecture in Freiburg in 1919. In Weberian terms, a state exists indeed when its governing body can successfully claim a monopoly over the use of force [or the means of violence] in a given territory. ${ }^{1}$ Therefore, the place of armed and security forces has loomed large in discourses of statehood.

Few African states have been able to claim success on these bases for any continuous period of time since many of these states became independent dominions in the 1960s. Colonial rule and its outcomes, not least in the form of arbitrarily drawn borders, posed a fundamental challenge to the sovereignty of the newly independent African states. The contestation experienced by these new states was easily predicted given that masses of people - kith, kin and identity groups - were split across the artificially created state boundaries. Arguably, incidents of border disputes in Africa might have been more difficult to stem, but for the 1963 insistence by the continental organization [OAU] colonially inherited borders were inviolable. It is also arguable that this very decision might have generated a corresponding increase in other contestation against the state in the civil wars and demands for self-determination in a number of African states. In some cases, one might argue, the process of purposeful state building did degenerate into a non-directed condition of state-formation. ${ }^{2}$

\footnotetext{
${ }^{1}$ Weber, Max (1957): Politics as Vocation. In: Gerth 1957

2 Bachmann, Olaf (2013), Quasi-Armies: Obstacles to, or Vehicle for, State-Building in Central Africa. King's College London (University of London)
}

Thus, Africa, more than any other region has in the last few decades experienced greater contestation to the state, given various instances of armed and violent conflict and civil wars. Weber would argue that in situations where no one group can gain a monopoly of force across the entire jurisdiction, then it is difficult to qualify these entities as states. Rather, what obtains empirically is a situation of 'statelessness'. Under these conditions, the need to build legitimate institutions of governance that would mediate the space of the state, manage long standing conflict and prevent further outbreak of violence, have been central concerns to African and external actors alike, in the effort to build viable, stable and peaceful states in Africa. There are divergences between the approaches of African and external actors notwithstanding this collective interest in the search for sustainable peace.

In general, African 'home-grown' approaches are organic and dynamic with variations in experiences and approaches across regions albeit with a normative framework at the continental level. External interventions in African states that experience armed conflict or civil wars are in large part about inserting into a long-standing conflict, a framework that enables the building of liberal democratic institutions with the expectation that this would lead to stable and lasting peace. $^{3}$

In effect, liberal peacebuilding interventions presumably help so called 'weak' or 'failed' states regain empirical sovereignty and/or juridical sovereignty, building the state as it ought to be. This often occurs in a number of ways including by restoring the rule of law, restructuring armed and security institutions and building their capacity to maintain and installing democratic governance over these institutions among other things.

\section{DAMAGE LIMITATION IN THE ABSENCE OF A STRATEGY}

As was observed for some time the state's fight for control is increasingly being taken over by new mechanisms states have given themselves to answer globalisation. States increasingly use the level of intrastate and supra-state governance, which equips them

\footnotetext{
${ }^{3}$ Richmond, Oliver/Franks, Jason (2009), Liberal Peace Transitions: Between Statebuilding and Peacebuilding (Edinburgh: Edinburgh University Press)
} 
with more leverage. This results in pooling and often sharing of power, but also in a diffusion of power at the national level. At the same time, and what was falsely according to our perception, considered a dwindling of statehood is actually a redistribution of responsibilities along the lines of efficiency. The benchmarks of this efficiency are thereby no longer the survival of the Weberian state, but the functional governance of community. This governance may include a strong formal political element, but it has proven to be of minor relevance in places where peace preservation was successful. Somaliland provides a calling example in this regard. Even if one looks at the apparent counterexample Somalia, where the fiction of a Weberian state is being maintained relentlessly, there are no ungoverned places. There are poorly governed places, if one applies ethical normative yardsticks. There are inefficiently governed places, if the Weberian or even democratic state offers the only possible target line, and there is a deficit in governance where open conflict leaves people at the mercy of the armed opportunist; but there is effective governance where it may be of limited efficiency, and there is ethical approval by the governed that we may not share.

However, in a vast majority of the last-mentioned conditions there is a level of political damage limitation under difficult circumstances that has not been achieved by an externally imposed standard fit-for-all statebuilding policy. Imposition goes only as far as it is in line with a conversation on the ground on how one wants to or should be ruled - on how community can settle with a working arrangement. As long as this conversation is ignored or even muted, and many hastily pressed through early elections in post conflict environments are to blame for such a grinding of emerging conversations, the relapse to open conflict is highly likely. ${ }^{4}$

The real challenge is that neither the African-led peacebuilding interventions nor the extra-African ones by the United Nations and other actors have achieved lasting peace across the vast majority of situations of conflict and insecurity in Africa and in a number of nonAfrican settings. Indeed, the situations of violent conflict relapse have become one of the greatest challenges confronting the UN peacebuilding architecture. ${ }^{5}$ As

\footnotetext{
${ }^{4}$ The Liberian peace process provides the perfect example for such a misplaced policy

${ }^{5}$ The Challenge of Sustaining Peace, Report of the Advisory Group of Experts for the 2015 Review of the United Nations Peacebuilding Architecture, 29 June 2015
}

such, the dogged adherence of the UN to the template approach of liberal peacebuilding interventions has come under sharp criticism in recent years.

In addition to already well-documented critiques of the state-building approach offered by the UN, new thinking about peace and the state in Africa is gradually emerging. The research projects, for example, on which this paper is based, make several arguments, central of which is the need to study the state and peace in Africa empirically - as it really is - rather than how it ought to be. This offers an opportunity to introduce historical as well as normative perspectives into any discussion about the search for peace and stability in Africa. A historical perspective is crucial for finding a contextrelevant and sustainable solution to the challenges to the state and long-standing issues of insecurity in Africa.

Issues at the core of such state-building conversations in Africa have been wide-ranging, but have tended to feature identity, governance of security, governance of natural resources, political participation and leadership succession, and equality of opportunity, among other things. These are part of the contestation in the statebuilding processes that have led at times to armed conflict. The capacity of the state to manage diverse populations' aspirations and to mediate multidimensional conflict across the board thus ought to be a key issue of concern to a state-building agenda.

\section{STATEHOOD IN THE CROSSHAIRS OF ANALYSIS - A MOVING TARGET}

The question is whether African states have ever been fit for purpose in this regard. Should the 'state' be understood through the lens of juridical sovereignty, as well as ability and willingness to oversee positive peace? If it is both, and this is implied in on-going studies at the African Leadership Centre (ALC) in 2015 through 2017, then the time may have come to return to previous debates on the nature of the African state. ${ }^{6}$ A rethinking of statehood in Africa must therefore accommodate particular questions and certain issues must be laid to rest.

One issue is the extent to which the Weberian focus on the sociology of the state, which has empirical

\footnotetext{
${ }^{6}$ Young, Crawford (1994), The African Colonial State in Comparative Perspective (New Haven: Yale University Press)
} 
sovereignty at the core, remains central to this discourse. Does the monopoly of force matter much when the African state is studied empirically today? What matters most in terms of empirical statehood in Africa? What role must now be ascribed to the military and security establishment, which represent the political and formal element of governance of the community? Governance that transcendences society as a whole and does not seem to be contained in the political formal government that one takes for granted as the one and only pivotal actor.

A second issue is the vitally important peace-making role of the state in Africa, given its origins as a colonial construct. This also highlights the need to problematize more comprehensively the nature of the State in Africa as opposed to the conception of the African state - this distinction hinting at the lessons countries and communities elsewhere could benefit from. In select cases, the very existence of the state in its current form [to the extent that a state exists; i.e. not a situation of 'statelessness'] is an impediment to sustainable peace? Is 'state-building' in some societies intrinsically problematic because some of the fundamental and irreconcilable 'conversations' relate to or challenge the very existence of that polity? This tension has to be addressed because there is no perspective known that would allow for an existing governance of community, no matter how technically successful, if it is not integrated into the increasingly globalised systems of collective security. The notion that the object of this, the state in Africa rather than the African state, also allows for generalisations well beyond the boundaries of this continent. Instead, analogies to, and investigations into, states in other regions will enrich the enquiry.

These issues and questions require careful empirical study and a comprehensive process of engagement with the issue of Statehood in Africa. Some propositions can be advanced based on an initial review of the state of the countries concerned. The key focus of new research is to generate empirical data on the nature of the state in Africa and its role in shaping key peace and security outcomes for the wider society. It is suggested that the concept of the state one hundred years after Weber's definition was introduced, could be found in a wider, extended concept of Statehood, which covers more than only the political formal element of the division of power. It might in a meaningful way take account of the informal, but legitimate economic and political elements of governance of community, which in their entirety form the social and political reality of a country.

A central question worth considering even if in a less significant way is the extent to which the issues raised above are mainly African issues. As has been observed for some time, economic globalisation competes directly with the reach of state power through supra-national corporations, some of which are worth in financial terms more than the majority of states in fiscal terms. The state's struggle for control is increasingly being taken over by new mechanisms states have given themselves to respond to globalisation: the new level of intra state and supra-state governance that equips the lesser adapted classical state with more leverage. The price to be paid is that the conventional strong force of legal sovereignty is consumed by this process. Ironically, at the same time it is attempted through political intervention to reproduce the state in Africa and elsewhere. It is from here that this paper draws its relevance to this volume. Could the same questions about the empirical sovereignty [as opposed to juridical] not be asked of countries such as the United States? In a strange coincidence of misfortunes, the US and Europe, and East Asia, where the subject of statehood seemed to have been settled for a number of centuries are experiencing new challenges to the state that are not far removed from those experienced by African states. This is the case, at least on the surface.

Arguably, the differences between European and US experiences on the one hand and the African ones on the other hand, are one of substance rather than degree. For one, the question of juridical sovereignty remains a settled one for states in Europe and North America. That of empirical sovereignty is open to debate when the new threats posed by violent extremism, terror attacks and armed violence are closely examined. The experiences of mass migration into Europe are at the intersection connecting Africa and European experiences more clearly. Questions might arise as to whether these threats represent a significant contestation that warrants a wholesale re-examination of the ideas of statehood. Yet, it is difficult to challenge a claim that the US cannot at this moment claim to have monopoly over the means of violence within its territory. Any attempt by the state to disarm the population would be violently rejected. At a minimum, in the UK and the US, Brexit and the election of Donald Trump are an indication of fragmentation in the conversations. It should be noted that these trends are surfacing 'silent conversations' that 
went for decades unnoticed and only resurged to audacity through the easy and massive access to internet fora. However, beyond a need for a re-tweak and renegotiation of aspects of statehood, the systems in both countries seem to be able to withstand such conversations, even if political radicalisation in each case is increasing at an alarming rate. This does not only refer to marginalised youth, but even more to a considerable degree the general political discourse. For the time being, and any apparent weakening of this capacity is worrying, the peace-making ability of these states is robust.

In the final analysis, all of this might simply be no more than a coincidence. While the experience of statehood in Africa might be readily a subject of further study and review, it is more challenging to bring the US or indeed Europe into a debate about building and sustaining peaceful and viable states.

In addition, how state-building and the state in Africa itself should be understood from a normative perspective remains a vitally important area for discourse. In this regard, the argument offered by recent research is that peace-building has to be an integral part of the state-building conversation occurring in a specific context and not an end in itself. ${ }^{7}$ This, however, brings a normative debate into focus: the state ought to in some way promote and facilitate positive peace. Thus, studying the evolution of the state and reflecting on the ways in which conversations across society have revolved around key issues to do, for example, with regard to the terms on which diverse populations in the target society would live together, might provide a viable pathway to sustainable peace.

To facilitate such a conversation, however, one has to analyse the interests in place and recognise that such interests are no monolith occurrences. Stakeholder centred policies are currently considered dernier cri among analysts of conflict resolution, but even this goes not far enough. Interested actors of a prospective conversation process often represent several and often even competing interests at a time. The problem is to carve out of these different strings the one that can best be aligned with an idea of the common good. Interaction between representatives of interests are more complex than inter-subjective exchange. Its complexity derives from the fact that it materialises in processes rather than negotiation red lines. Positions are non-static even if people initially hold strong opinions. The processes that underlie the conversation of how one wants to live together must hence be analysed. For this reason, we suggest a model to describe the complexity as presented in the following sections.

\section{BETWEEN A ROCK AND A HARD PLACE}

In much of Sub-Saharan Africa, where even the Weberian state did not impose itself on communities due to an original lack of legitimacy of its representatives, this development is obviously overtaken by a fierce conflict between the admirers of sovereign law and order and result-oriented actors at all conceivable political levels. However, this conflict has not been recognised as such until now. Powers are tearing the communities they mean to represent into diametric directions, often without realising this: the different perceptions carry a historical default because throughout the age of imperialism a Westphalian structure, in the form of the colonial state, was considered most appropriate for Africa. Now, after decolonisation, only a Weberian structure is considered appropriate for regions for which the Northern, currently more advanced democratic state, is considered as beyond a realistic aspiration; even if only out of lazy arrogance.

There may be disagreement on whether to aim at the democratic state as the main guarantor of structural peace, but the claim for at least a Weberian structure is the valued benchmark both in the Global North as well as in the South. However, both in the North and the South the alienation between the representatives of the formal state and the citizen increases and legitimacy is sought elsewhere, typically resulting in conflict relapse in much of the developing world. Hence, these targets have to be aliened to make them productive and to gain legitimacy. Importantly, from the beginning an interstate level of governance has to be included into a new extended system of political order because the conventional state will not remain the same overwhelming centre of political gravity.

From many years of close cooperation with the UN and regional organisations in conflict research in developing countries it is understood that threats to

\footnotetext{
${ }^{7}$ Olonisakin, 'Funmi and Muteru, Alfred (2014), Reframing Narratives of Peacebuilding and Statebuilding in Africa, ALC Working Paper, Number 16, February
} 
security come from different directions, grow from 'greed and grievances', and do materialise at any level of governance of community (from the barrio or village to the UN). It is no longer a contested view that the establishment of a functioning apparatus of the governance of community is the one precondition for general stabilisation that cannot be circumvented. It is now necessary to formulate measures to counter the eroding meaning of authority and cooperation. Such countermeasure may exist and be visible in all communities that successfully keep the peace.

So far, however, the focus of interest was pointed to lessons learned from failure. ${ }^{8}$ A new strong emphasis has instead to be put on the reality of thousands of pockets of peace, of all sizes, that have been left out of sight behind a fog of analysis of violent conflict. ${ }^{9}$ Having said this, peace-building has become synonymous with state-building. Such pockets of peace existing within highly volatile regions have been overlooked when it comes to drawing lessons for political learning. A discourse on why communities keep relapsing into conflict was maintained at the expense of researching why communities defied war under seemingly overwhelming pressure to give up on it. The sum of such efforts has to be taken in account when it comes to analysing actual governance of security, and therefore a perspective for a peaceful governance of community. It will be defined in its wider context as Extended Statehood.

\section{EXTENDED STATEHOOD}

Extended Statehood represents the totality of stakeholders involved in policy-making, and in the case of state-building and polity-making. Indeed, the fact that these stakeholders of legitimate governance of community include formal and informal political and economic elements makes an overarching approach necessary. The model suggested, as indicated above, however, is one representing processes rather than actors. It is at a higher level of abstraction than a mere social-networking model or similar inter-subjective patterns would allow for, and as they are known from the sociological and political-scientific. The model in its entirety represents the complex political culture of a given community. It also reflects this community's locus

\footnotetext{
${ }^{8}$ More and more often soldiers become part and parcel of multi-dimensional peace-building missions, a fact that still constitutes a certain paradox.
}

among adjacent or geographically far communities she communicates with. As will be pointed out along the following demonstration, the identification of interacting agents (both as drivers and spoilers of policies) will be amplified from a mere inter-subjective level to an interrogation of outcomes of processes as we observe them within and between certain spheres of Extended Statehood.

Both the creation and implementation of governanceenhancing policies can, therefore, be described as functions of a multiplicity of interacting processes between and among the spheres of governance as defined below. The main purpose of the suggested model is to translate the seemingly inaccessible academic body of knowledge about a given political and social community into a graspable form, and then invite a feedback loop with potential practitioners in the field of state-building, who are often confined to restrictive terms of reference. By this means both will benefit, the former by valuable check of the validity of abstract interpretation, the latter through a comprehensive account of the circumstances and inconsistencies the project may run into.

\section{HYPOTHESIS}

The status of governance includes far more relevance to peace-making than the mere state of the state, a political construct that gradually generates into a component of modules in an increasingly complex environment. The problem is to identify the interconnectivity of different levels and forms of governance, its hierarchical structures, and the practical instances in which the hierarchy may temporarily or systematically become of minor importance. As a result, we shall have a coherently articulated globally shared system of governance, which is flexible and thus selfperpetuating. In other words, stability would arise from what appears a chaotic system. At the same time, it offers a model of understanding and conceptual auto location for every actor involved. We propose to introduce a concept encompassing Max Weber's epochmaking definition of the state but go beyond it to cover all levels of pertinent governance of community. The confusion about strong states or powerful states, about weak states or composite forms of rule is partly due to a

\footnotetext{
${ }^{9}$ Pockets of peace of all sizes may refer to entire countries like Jordan now or Botswana when it was surrounded by war.
} 
definition of the state that does not even cover the USA any more as Weberian state. ${ }^{10}$

The new paradigm offered in this paper will also be tested against the validity of Weber's conceptualisation of forms of governance considered functional as well as non-functional. This does not mean that empirical functionality is the only testing stone of a state, but that it provides one indicator for the reason why the idea of the failed state or limited governance results from an under-complex understanding of the actual reach of statehood, namely, because it limits the perception of governance of community to a security and safety related political formal realm of governance, within which the military is the most prominent element of the bureaucratic apparatus. Accordingly, the nature of the state shapes its approaches to security governance and (in-)capacity to achieve expected security outcomes. If, however the way in which a community is governed is a key variable in preventing, managing and transforming (or promoting) armed conflicts and insecurity, the scope of the concept of community governance has to be adapted as well.

On the one hand, and countries in Africa and the Middle East may illustrate this, there is persistence of armed conflicts, widespread pockets of localised insecurity, and failure to achieve radical transformation in spite of local and international institutions implementing a plethora of targeted interventions over the last three decades. On the other, emerging security challenges (e.g. violent extremism, organised crime, communal clashes and other variants of sub-national and transnational violence) continue to expose the limitations of dominant policy assumptions and approaches to security in developing countries. Not unexpectedly, there is a burgeoning alternative of security systems outside of the recognised state. Citizens and communities are increasingly meeting their security needs entirely or partially outside of state-led processes and mechanisms. Correspondingly one observes an intrusion of legitimate control of conflict mitigation into unconventional institutional settings. In the Global

\footnotetext{
${ }^{10}$ After all, Weber's successful claim of the monopoly of legitimate control over the means of violence leaves us with a government in Washington that could not disarm the population even if it aspired such a policy. The anachronistic 2nd amendment invalidates the monopoly since the abolishment of the historical militia system. The US do not delegate the power anymore, it has lost it beyond retrieval. ${ }^{11}$ Dr Eka Ikpe rightly pointed out during the ALC research day in Nairobi in May 2017 that the popular idea of an
}

South legitimacy is more often than not allocated to one or several elements of governance of community, which exist side by side with what we consider a state. In many countries the military comes in forms that fluctuate according to their use rather than according to the legal frame it is supposed to act within. Non-statutory military has hence to be taken in account.

Contemporary research and policy debates, and interventions to address violence and insecurity, continue to take place with little or no attempt to revise and rethink the nature of the state and the specific political culture it is based on in respective cases. The contemporary discussion on hybrid states and politicoeconomic interference in governance are helpful; however, they remain unrelated and lack interlocking logic. An additional dimension to this new reality of empirical statehood (to expand on Jackson's Quasi State idea, who pointed out statehood existing as a hollow shell within the international world but meaningless domestically) that has to be taken into account, is the growing impact of multi-layered governance. Its impact at all levels of decision-making is virtually irresistible as it is a uni-oval twin of economic and social globalisation. ${ }^{11}$ Rather the form of governance follows the function, even if only incrementally. In the wide world of governance of community in an emerging world of multi-level governance Weber's state covers just one of the four elements that represent governance of community at the national level: the political formal one. Its communicating elements at every level are political informal, economic formal, and economic informal, agents or organisations.

This wunderliche Vierfaltigkeit, this miraculous quadruplet, to borrow from Clausewitz's illustration of the nature of war, repeats itself at all levels of governance of community. ${ }^{12}$ This includes the national level, whereby the political formal sphere represents the Weberian state, the local, and sub-national levels below the national community level; and the international, and global community levels of governance, above the state. It is important to keep in mind the inherent hierarchy

alleged state - market dichotomy can be neglected for two reasons: First, it represents another diffuse binary actor centred analytical scenery of limited explanatory value; second, it disregards the highly competitive and often irrational political market.

12 The adjective wunderlich has been translated by Howard/Paret (1989: 89) with 'paradoxical', which does not fit a 19th century connotation of the word. 
between these levels, which causes additional, at times overarching references and repercussions in and for governance between them.

Table 1: The National Level of Governance of Community; Interacting Spheres.

\begin{tabular}{|c|c|}
\hline $\begin{array}{c}\text { Political formal } \\
\text { governance } \\
\begin{array}{c}\text { The Weberian } \\
\text { State }\end{array}\end{array}$ & $\begin{array}{c}\text { Political } \\
\text { informal } \\
\text { governance }\end{array}$ \\
\hline $\begin{array}{c}\text { Economic } \\
\text { formal } \\
\text { governance }\end{array}$ & $\begin{array}{c}\text { Economic } \\
\text { informal } \\
\text { governance }\end{array}$ \\
\hline
\end{tabular}

Extended This still very static model, however, can only be seen as painted with a broad brush. As mentioned above, what looks like a mere compilation of groups of corporative actors, cannot represent a complex society. Rather the elements display a concurrence of influences transported through political and social processes. Indeed, a personal union of actors would easily be imaginable to exist in several, maybe even all of the spheres at hand. Populating the spheres in the graph can make this obvious, with different patterns recognisable in every particular community. The spheres exist at a level of abstraction that portrays the interaction or insulation between and among processes. They hence have to be read as functions of the political, economic, social, religious, ideological, and even geographically specific processes depicted. This allows one to use the model to describe a status quo in a very transparent and easily accessible way, and allows for an outsider to get an immediate grasp of the situation on the ground for each conceivable case of governance or the lack thereof.

A step farther, the model takes a shape representing relative influence of the different functions of statehood as they marginalise through otherwise hardly explainable policy outcomes. The relativity among actors has been described ample times, but the relativity of functions of processes is more accurate in describing reality. Contradictions in policy-making, shifting alliances, newly emerging players, to name a few, can be included and if carefully applied, be predicted through this method of description. Below one can see a rather simple application as to describe forms of statehood that vary from a functional state in the conventional understanding to its respective dysfunctional opposite. The formal spheres of government, both political and economic, may be relatively strong vis-a-vis the informal spheres, which would account for a stable state given the current discourse on the delimitation of strong and weak state. By contrast the weak state would be expected in a setting like shown below, with the Central African Republic, Mali, or the DR Congo quickly jumping to mind.

Graph 1: The National Level of Governance of Community; Interacting Functions in Relative Impact
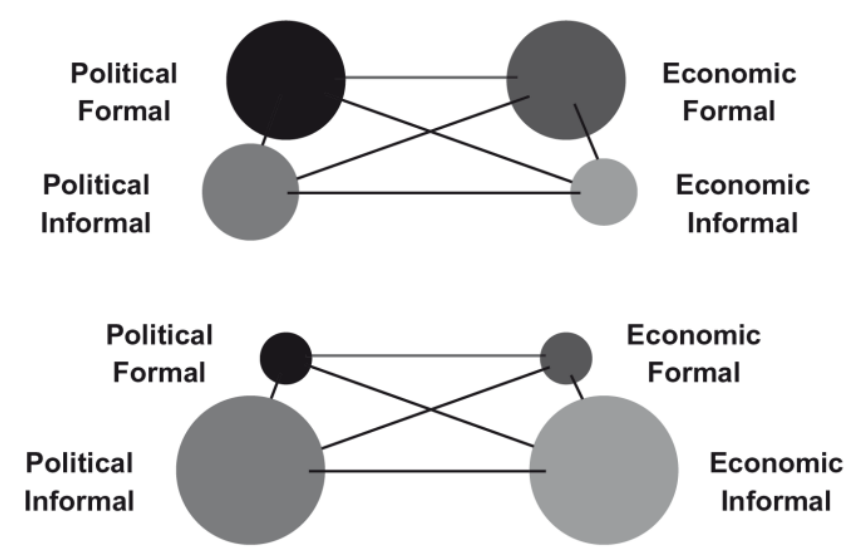

However, firstly, and as demonstrated by our example of the USA, a political formal state can be relatively weak (here even fitting the aspirations of the founding fathers), but still be imbedded in a function environment of Extended Statehood. On the other hand, the functions of political processes may not result in a stable formal Weberian state without resting within a workable Extended Statehood.

Most importantly, the proposed pattern repeats itself (see Graph 2) at different levels of intertwined multilevel governance. One recognises the five relevant layers of governance as situated at the local level; at the subnational level; at the national level; at the international and/or regional level where this applies; and at the global level. So far, the impact of political formal multi-level governance has been recognised, however, very much so at the neglect of the other three that factually interact within and across levels of formal and informal governance. This impacts on the role and self-perception of soldiers. 
Graph 2: Multilevel Governance of Community

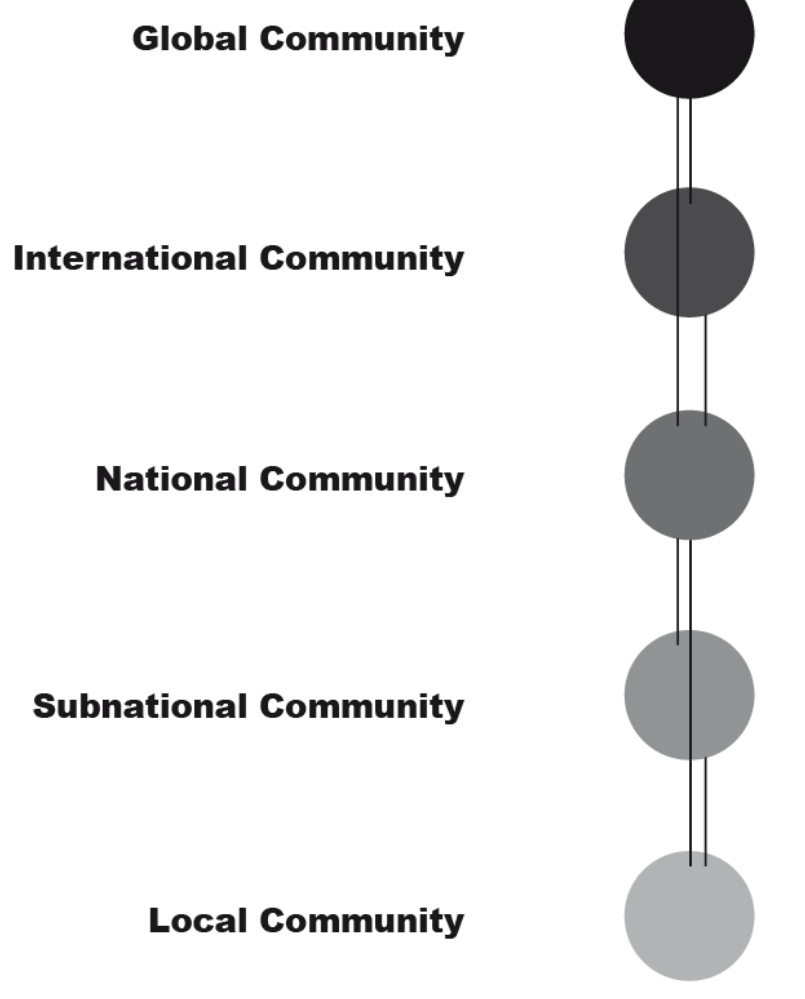

On the Graph 3 offers an overview of the scaffolding of the proposed model, which is of astounding selfexplanatory power. When confronted with the model, scholars and practitioners were instantaneously able to identify the conventional state as a meaningfully integrated component of a wider coherent system. Such a non-trivial but accessible representation of reality offers itself as a tool of high quality inter-subjective understanding. The difference in the composition of the proposed spheres (here in the form of bubbles in a static 'resting status') as obvious between cases ranging from stable and democratically governed communities to ones that lack the coherence of a robust bureaucratic and unified formal legal system within an uncontested territory so far have not produced an example that could reject the model as unsuitable. This model will serve a twin purpose to both the interested researcher and to the practitioner exposed to the reality in the field. If, for instance, one sends soldiers on a mission to Mali, one needs to equip them with an understanding of what he or she encounters when meeting a uniformed carrier of arms, and what or whom this person represents. On the

\footnotetext{
${ }^{13}$ Political formal is always represented by the government, economic informal, for instance, can range as far as from
}

other hand, a quick feedback from the field to the academic researcher is possible by application of this graphic device.

Graph 3: The Scaffolding of the Extended Statehood

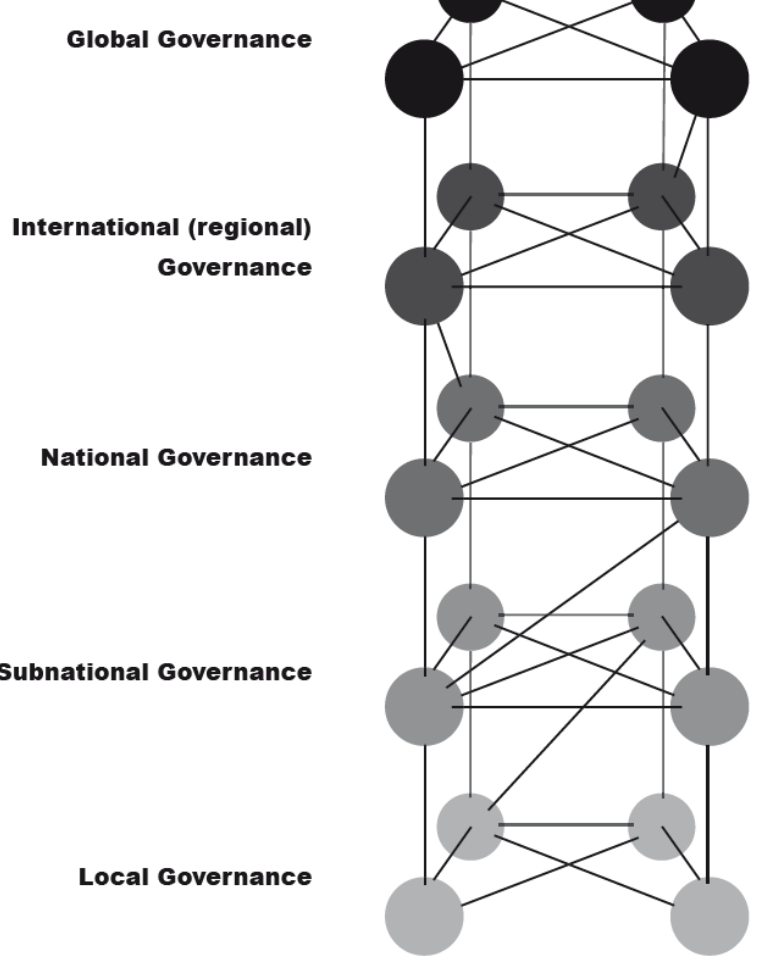

Whilst the political formal realm always remains based on Weberian or at least Westpfalian patterns of the state, all other spheres can easily be filled with the respective alternating forces of interest, power, or sense of belonging. Whilst political informal settings may be recognised as lobbying or even nepotism and neopatrimonialism, the essence of the two would quickly be a valid description for clientelistic systems that contradicts the notion of political formality par excellence. Economic informal spheres may have a different connotation in the case of communities that pride themselves of working trade unions and entrepreneur organisations from communities in which organised crime represents the most prominent form of informal economic power, but some degree of corruption would be assigned by the onlooker on all systems subject to our model. ${ }^{13}$ The strong impact of informal economic power at the international (e.g. but not exclusively regional) and global level of the governances of community speaks in favour of such a

development NGOs over Mafia to Tontine's of francophone Central African women 
pattern that duly represents its potential or actual impact. Economic formal spheres at all five levels of the model marry themselves often to the respective political formal order but are more often a function resulting from the interference of actors from the economic informal sphere.

It has to be repeated here that this model illustrates on-going inter- and intra-level processes of governance in a presentation best described as a snap-shot, or logical second. As such it provides the most handsome tool for any mission pre-deployment training or for high urgency rapid deployment. Apart from the analytical value one is equipped with a mapping and reconnaissance tool for digestible information. Alas, and this has to be emphasised to avoid misunderstanding: the model represents processes between spheres of power and interests that may be conflicting at the personal level of people involved or at the institutional level of organisations suffering from historical and legal path dependencies. As a result, it discloses the complex and multi-layered reality of a political culture. It protects the analyst from bias resulting from selectively concealed information.

In contrast to conventional models of understanding the state, this recognition of the broader and more coherent system constituting Extended Statehood allows for more adaptability and greater flexibility. Although the traditional value of national sovereignty is undermined by this process, the state still remains the key actor controlling the powerful military elements of society despite the importance of other elements of Extended Statehood. A form of governance that neglects the national level of formal politics is neither aspired to nor would it make sense. After all, even without the power of globalisation human governance is based on a community that is defined and perceived as neighbouring to something and somebody. Regional and Global governance of community is unthinkable without this common frame alone for reasons of reliability.

With regard to the sub-national and local levels of governance, their crystallisation point of reasoning and orientation is again the national state level. It is defined

\footnotetext{
${ }^{14}$ It is surprising to notice the extreme nationalism that has developed in the DR Congo ever since 1960 even when the population suffered from less communication and its number went up from an initial 17 million to now 75 million. Similar to the
}

and understood as forming part and parcel of it. Competing interests and power dynamics may make this forget for some time but, as other examples in this volume demonstrate, eventually the sense of belonging to the country is unalienable from a national identity. ${ }^{14}$

\section{CONCLUSION}

Formal statehood at the national level may become in the future reduced to the relatively small, but vitally important role of the provision of safety - and this will call for a wider definition of statehood beyond the political formal 'state' as we know it. After all, intra-state relations still form the basis of regulation and governance that shape both inferior and superior levels of statehood. Having said this, one has to add that direction and sense of hierarchy between the different levels are not necessarily subject to agreement. Classical hierarchical thinking at times faces legitimate and organised resistance from officially inferior actors. There is a paradox to enquire inherent to this research. In the end it all comes down to legitimacy.

The Weberian and even the democratic state are not inclusive enough - or in some places anymore - to reflect the social reality it exists in. The legitimacy of classical statehood is slowly, but constantly eroded from different directions. At the same time the disappearance of conscript military service, which negotiates between new fiscal limitations of the state and the drive to the banalisation of the military service as a mere profession, makes the proverbial candle of sovereignty burn from both ends. The state, however, is still attributed as the key actor to control the very powerful military elements of society. However, it will have to compete for legitimacy as the military comes in new and different forms, not all of which are loyal part of the state apparatus.

We offer this model to the practitioner and soldier who either serve as part of a project to maintain or erect a state or become void of professional aim and meaning. As a result, one has to reconsider a definition of the target of peace-building in order to equip the soldiers of troop contributing countries with a strategic aim for

Hambacher Fest period of romantic Germany, there is more manifest nationalism than empirical unified statehood on Congolese territory. The DRC never had a functioning formal political sphere ever since independence and remains at a status of stalled state-formation. 
guidance. Without such an aim their efforts will be futile and further erosion of the legitimacy of the state as such would result. Hence this paper suggests an update on the understanding of Extended Statehood and a method of translating this improved understanding into a workable tool to practitioners in the field.

\section{BIBLIOGRAPHY}

Babatope, Ebenezer (1971), Military Intervention in African Politics; a Comparative Study (Ebino Topsy Publishers: Lagos)

Bachmann, Olaf (2013), Quasi-Armies: Obstacles to, or Vehicle for, State-Building in Central Africa (King's College London: University of London)

Lemarchand, René. AandLegg, Keith (1972), Political Clientelism and Development: A Preliminary Analysis, Comparative Politics, 4: 2, pp. 149-178

Mazrui, Ali Al'Amin (1973), The Lumpen Proletariat and the Lumpen Militariat, Political Studies, 21: 1, pp. 1-12

Ogot, Bethwell A. (1972), War and Society in Africa; Ten Studies (London: Frank Cass)

Olonisakin, 'Funmi and Muteru, Alfred (2014), Reframing Narratives of Peacebuilding and Statebuilding in Africa, ALC Working Paper, Number 16, February

Richmond, Oliver and Franks, Jason (2009), Liberal Peace Transitions: Between Statebuilding and Peacebuilding (Edinburgh: Edinburgh University Press)

Weber, Max (1957), Politics as Vocation (In: Gerth 1957)

Gerth, Hans Heinrich (Ed.) (1957), From Max Weber: Essays in Sociology (London: Routledge)

Young, Crawford (1994), The African Colonial State in Comparative Perspective (New Haven: Yale University Press) 